Toussaint Louverture and the American Civil War 
This page intentionally left blank 


\section{Toussaint Louverture}

\section{and the American Civil War}

\section{The Promise and Peril of a Second Haitian Revolution}

Matthew J. Clavin

\section{$\overline{\text { PENN }}$}

UNIVERSITY OF PENNSYLVANIA PRESS

PHILADELPHIA 
Copyright (C) 20Io University of Pennsylvania Press

All rights reserved. Except for brief quotations used for purposes of review or scholarly citation, none of this book may be reproduced in any form by any means without written permission from the publisher.

Published by University of Pennsylvania Press

Philadelphia, Pennsylvania I9IO4-4II2

Printed in the United States of America on acid-free paper

IO 9877654322 I

A Cataloging-in-Publication Record is available from the Library of Congress ISBN 978-0-8I22-4205-8 
For the loves of my life, Gladys, Madeline, Joseph, and Joshua 
This page intentionally left blank 